\title{
Trans-Rational Cash: Ghost-Money, Hong Kong and Nonmodern Networks
}

\begin{abstract}
In this essay, I examine through Bruno Latour's concept of nonmodern networks the intersections of the hyper-modernity of Hong Kong's 'real' money economy with that of an economy of ghost-money that, through the act of burning, serves as an offering to the dead and the divine. The essay reconfigures Latour's 'modern constitution' as it relates to philosophy, myth and modernity as they are organised around the values of a currency that trespasses all boundaries.
\end{abstract}

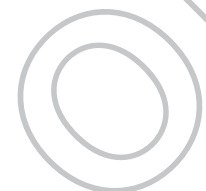

To shuttle back and forth, we rely on the notion of translation or network. More supple than the notion of system, more historical than the notion of structure, more empirical than the notion of complexity, the idea of network is the Ariadne's thread . . . (Latour 1993: 3)

After carefully folding a bundle of $\$ 100,000$ bills of ghost-money - embossed on one side with the image of the Emperor of the Underworld and on the other with the façade of the Bank of the Underworld - I place it carefully into the furnace outside of the Temple of Man Mo, 124-126 Hollywood Road, Hong Kong, and watch my offering catch fire, turn to curling black ash and ascend toward the sky in smoke as it makes its way to my ancestors on the other side of experience. Coils of incense hanging from the ceiling burn with infinite patience along their spiral pathways toward extinction, filling the inside of the temple with a pungent aroma and marking a different time from that of the hypermodern streets just outside.

The Series 2006 note, backed by the Hellbank Corporation and assuring us that 'this note is currency in the ghostdom', is authorised by the signatures of Mary Ellen Withrow and Robert E. Rubin, President and Fit-President, respectively, of the Banking House of the Underworld (and who also happened to serve as the Treasurer and Secretary of the Treasury under President Bill Clinton). There is no money, after all, without institutional legitimation and with a slight twist of signification this money traverses that boundary between the living and the dead. 
As a nomadic gweilo, I am not sure if my offering will be accepted by those on the far side of visibility, but the performance of the ritual itself is what is important. I bow toward my father, my in-laws, my grandparents, uncles, cousins, the never-known siblings who passed away before they were born, and all the others who walk with me as the narrative of modernity - with the trans-, hyper-, post-, and non- always at work - folds upon itself like the creased joss paper.

The empirical and transcendent brush across one another as the living turn toward the dead, who, expecting us, are still in need of cash:

The dead, like the living, have wants and needs in the netherworld, including material goods such as a spirit/soul house (lingwu), which are necessary to keep the ancestors from becoming hungry ghosts' and to help them live through the required period in the netherworld. (Kuah-Pearce 2011: 142)

The ritual of burning honours the dead and the gods, protects me from the ghosts that hunger for a home and restores the balance to the whole by covering at least a fraction of the debt incurred by the fact that I am alive. Ashes to ashes.

In its most general sense, the traditional understanding of the world is the

system of cosmic phases known to all Chinese as yinnyángwŭxing . . . the process of continuous cosmic renewal. It is an ultimate sacred postulate insofar as it is a fiat of discursive reasoning behind which there is no higher logical category ... the assumption that all things are constituted in their mutual relationship rather than in their individual substances. (Blake 2011: 82)

On the other hand, with its progressive sense of time, its orientation toward the virulent growth of capital and the correlative depletion of the earth, and with its rejection of the old ways in favour of the measurable, utilitarian and scientific, modernity wants nothing to do with such rituals of fire except to label them 'superstitious', 'antiquated', and then to create a tourist industry around them.

Communist modernity, which operates (quasi)visibly in Hong Kong, would prefer to do without such practices altogether, but it now puts up with them since they provide social and cultural cohesion, the 'harmony' of the family and the state. (There are, however, ongoing warnings about the burnings and the increase of air pollution.) Ghost-money is a ritual assemblage connecting the present across a multitude of differences, and, for this situation, we need a more comprehensive language than 'tradition' and 'modernity', since these simultaneously co-exist.

In We Have Never Been Modern, Bruno Latour analyses the organisation of forces at work in the 'Modern Constitution' - beginning with the scientific and political revolutions of the seventeenth and eighteenth centuries - as he shows how it has operated and how we might re-imagine other means of participating in the world through what he calls 'nonmodern networks' (which are emphatically not anti- or un-modern). This thread of Ariadne, 
Which can only be encountered in a labyrinth, allows us to pass with continuity from the local to the global, from the human to the nonhuman. It is the thread of networks of practices and instruments, of documents and translations. (Latour 1993: 121)

There is certainly a 'capitalist hegemony' at work in Hong Kong - with its speculative property market, the trading floors of the major banks and the tax havens provided - but this hegemony cannot be seen as the 'cause' of

${ }^{1}$ Latour uses 'the Middle Kingdom' to indicate the nonmodern throughout We Have Never Been Modern, linking it on occasion explicitly with China. Although I take his point that everything occurs in media res - without origin or endpoint - I am not sure that 'middle' is the best term, since it indicates known and measurable ends, to indicate the emergence of a network sensibility. I prefer the 'between', but there is no perfectly adequate descriptor. The Middle Kingdom in the traditional Chinese sense is certainly not applicable to rewriting the Modern Constitution. 
the rituals of ghost-money, or at best, only one of many over-determined causes. These rituals go back thousands of years in Chinese practice and we know that fire is one of the fundamental transformers of substance as the human folds itself as the human. ${ }^{2}$ Capitalism is very much a late-comer, emerging through the history of commerce, from the ancient world of Promethean fire that claims technology for its own, and then through the fires of the industrial transfiguration of the earth. ${ }^{3}$ Money is an accelerant; it burns.

Latour argues that the Modern Constitution sought the 'purification' of categories such as politics, religion, subjectivity and knowledge and

renders the work of mediation that assembles hybrids invisible, unthinkable, unrepresentable ... [in it] the obscurity of the olden days, which illegitimately blended together social needs/and natural reality, meanings and mechanism, signs and things, gave way to a luminous dawn that clearly separated material causality from human fantasy. (Latour 1993: 34-35)

The world, desiccated, became disenchanted. But although the 'hybrids' have always existed, the attempted purifications have now become visibly riddled by habits, actions and assumptions that modernity thought it had excluded forever in its steady march of enlightened progress. The hybridity of ghostmoney that gives us an entry into re-thinking the (non)modern as history restitches itself into something not predictable by models of development, progress or of the more-and-more.

In Cantonese, the word for 'ghost-money' - or 'hell-money' - is zi-zaat, paper goods, which includes a range of paper objects beyond money itself. I prefer the term 'ghost-money' because of the ways in which it precedes and post-cedes the theology of the Christian term 'hell'; because of the ways in which it points to traces of visibility, power, need, departure and return; and because of the many ways in which it resonates with contemporary theories

${ }^{2}$ For excellent analyses of the historical development of these practices see Blake (2011), Hou (1975) and Scott (2007).

${ }^{3}$ In the preface to his 1841 dissertation, The Difference Between the Democritean and Epicurean Philosophy of Nature, Marx identified his own, and philosophy's, task with that of Prometheus. 'Philosophy makes no secret of it', he writes,

[t]he confession of Prometheus: 'In simple words, I hate the pack of gods' (Aeschylus, Prometheus Bound) is its own confession, its own aphorism against all heavenly and earthly gods who do not acknowledge human self-consciousness as the highest divinity. It will have none other beside. But to those poor March hares who rejoice over the apparently worsened civil position of philosophy, it responds again, as Prometheus replied to the servant of the gods, Hermes: 'Be sure of this, I would not change my state / Of evil fortune for your servitude. / Better to be the servant of this rock / Than to be faithful boy to Father Zeus' (Aeschylus, Prometheus Bound). Prometheus is the most eminent saint and martyr in the philosophical calendar. 
of the spectral from digital technologies to deconstruction. Everybody needs cash, for there are always exchanges to be made and debts to be paid, but how is it that ghost-money can cross that most impassable of divides, that it can serve as a network of exchange in the land of the dead and of the divine?

Money, ghostly or not, is and always has been trans-rational, straddling the rational and the liminalities that criss-cross it, operating along the sinuosity of interfaces between the rational and its multiple others. Money moves; money is the magic of asynchronous and asymmetrical exchange. It is the universal equivalent, the power of alienating homogeneity that makes different things translatable into other things via the transfiguration of cash or credit. 'Proof of the netherworld beings is in the way money circulates' (2011: 60), as Blake reminds us.

That which appears to be real money in the dark of night, "night money,' becomes ash in the daylight. It reverses the usual flow of burning paper money to send to the netherworld. Money, persons' lives, and other vessels of value flow in interconnected circles that connect the temporal with the eternal. The flow of money transcends questions of what is real and what is unreal. (Blake 2011: 60)

Money cannot - and never has been able - to operate apart from the magical, the excremental, technological, material, numeric and the rational, as the calculation of differences into the one lies at the heart of money.

The rationale as the formal system of the logical emerges from Aristotle's basic law of non-contradiction: $A=A$. A never equals $B$. A proposition can be true or false, but not both, and the state of affairs is the state of affairs and not otherwise. The formal logic of syllogisms is eventually bound up with the logic 215 of verification through scientific experiment and mathematics and thus, through a much denser itinerary that this encapsulation can follow, we enter an age in which technology and its quantifiabilities become the carrier of the true (as well as the good). The logical in this form is a purification of truth, exorcising hybrids that gather around ambiguity and figurative language. There are many versions of this history, but John Berger summarises a particular interpretation when he notes that the rationalist dream of the nineteenth century was that

$[\mathrm{P}]$ recision would replace metaphysics, planning would resolve social conflicts, truths would replace subjectivity, and all that was dark and hidden in the soul would be illuminated by empirical knowledge ... [T] he unachieved positivist utopia became, instead, the global system of late capitalism wherein all that exists becomes quantifiable - not simply because it can be reduced to a statistical fact, but also because it has been reduced to a commodity. (Berger 2013: 72)

Commodification + quantification $=$ the visible truth of fact. This is the age of econometrics, another moment in a long history of such moments that takes as its task the exclusion of the non-rational as a means of constructing a socialised narrative of modernity that is a rationalised sphere of utilitarian predictability. 
The nomos of the oikos in its guise as econometrics and rational-agent theory fantasises that it can disregard the non-rational in the incandescent light of the power of a quantitative predictability. With ghost money, however, the laws of number and of non-contradiction do not hold; the rational is traversed by the trans-. The trans- serves, on the one hand, as a connector of similitudes, for the inhabitants of the other world also need

items of personal finance - the checkbooks savings account books with withdrawal and deposit slips, ATM cards, and credit cards all made to scale and drawn on the Bank of Hell . . . The credit cards, it should be noted, bear the image of the King of Hell, and colo[u]rs (greenish blue, white, and black) and design elements that are suspiciously similar to the American Express card, providing an otherworldly twist ('Don't leave this world without it') to their advertising slogan. (Scott 2007: 126)

On the other hand, however, the trans- also serves as a differentiator between domains of difference, in this case the living and the dead, as well as between the rational and its others among the living. ${ }^{4}$

The trans-, partitioned within itself, is the sign of what Latour calls 'translations', 'mediations' and 'networks', all of which keep everything trafficking with everything else, incessantly changing tempos, spaces and codes across a fluidity of interfaces. Such concepts indicate how the 'mythical' continues to co-presence with the rationalities of the digitised hypermodern of the overand under-world financial system of Hong Kong. Neither dichotomies nor chronological sequences, these are connected trajectories of networks of nonmodern hybridity, which, briefly,

adds instead of subtracting, fraterni[s]es instead of denouncing, sorts out instead of debunking ... A nonmodern is anyone who takes simultaneously into account the moderns' Constitution [the presumed clean separation between Nature and Society since the seventeenth centuryl and the populations of hybrids that that Constitution rejects and allows to proliferate. (Latour 1993: 47)

${ }^{4}$ Derrida, analysing multiple uses of the trans- in the folies of the architect Bernard Tschumi, notes that

trans- (transcript, transference, etc) and, above all, de- or dis- . . These words speak of destabilisation, deconstruction, dehiscence and, first of all, dissociation, disjunction, disruption, difference. An architecture of heterogeneity, interruption, non-coincidence. But who would ever have built in this manner? Who would have counted on only the energies in dis- and de-? No work results from a simple displacement or dislocation. Therefore, invention is needed. A path must be traced for another writing. (Derrida 1997: 333) 
In the emerging nonmodern Constitution, myth and rationality, the primitive and the progressive, are sorted differently from the modernist version, in which one version of rationality will vanquish its others. '[O]ne needs to "think other"', as Jane Guyer has observed, 'precisely about number, measurement, and money in the awkward and dangerous present because they are such powerful constructions in a quantified and insurgently commercial world' (Guyer 2004: 174-75). Nonmodernity helps us with this task of 'thinking other', a now clichéd phrase that must nonetheless continue to spur a vigilant re-examination of what we take to be the 'real'.

It is not as if these debates have only now, at the pinnacle of the present, appeared. They have been occurring for as long as the Modern Constitution has been taking shape (if, in fact, not since numbers and the gods parted company). Commenting on Ernst Cassirer's philosophy of symbolic forms that describes the mythical 'stage' of cultural development - to take but one example - Heidegger observes that:

What is later conceptually distinguished as body and soul, or life and death, is indeed also always already actual for mythical Dasein, but in the mode of magical power, according to which what is dead also is, and a force of the soul makes itself known even when the human met with is not encountered bodily .. Only first at higher levels does the magical daemon become daimonion and genius, in such a way that Dasein in the end comes to determine itself not as an alien power but rather from out of that for which it is freely capable, from itself and for itself as an ethical subject. (Heidegger 1997: 185)

The 'alien' and the 'itself' are networks of exchange. The 'higher' level here is identified with the Socratic inception of philosophy, who, as one who still listens to the genius of his daimonion - which only knows the 'not' and the secrets of music - proves himself a boundary figure that straddles the mythical and the emergence of the rational as the 'proper' logic of philosophy (which I take to be fundamentally related to the tasks of modernity).

But if Platonic philosophy participates - against its will, as it were - in both the mythic and the rational, it nonetheless labours to establish the rational as the ideal, as both method and goal, as it sets the stage for putting mathematics and a certain form of philosophical abstraction into high gear. This enormously powerful shift in human history is one moment of enlightenment. Another is that of the seventeenth and eighteenth centuries, for which Kant can stand as a kind of culminating representative. Both the ritual practices of Christianity as well as the 'superstitions' of non-European, non-Enlightened cultures come under the attack of critical rationality. These series of enlightenments, however, do not at all show how the world organises itself at the Temple of Man Mo on Hollywood Road.

Enlightenments proliferate and

when the nineteenth century invented the social sciences, precise knowledge of society and its laws made it possible to criticize not only the biases of ordinary obscurantism but also the new biases created by the natural sciences ... it became possible to distinguish 
the truly scientific component of the other sciences from the component attributable to ideology. (Latour 1993: 35)

Ideological critique is born alongside the social sciences and ghost-money superseded by the science of economics and safely locked away in the underworld of the primitive stage of the development of technocapitalism - should therefore vanish like smoke. Rational and scientific critique, from the standpoint of the modern, dissolves the mirage of illusion.

But as the woven fabric of modernity begins to fray along all of its boundaries - and as the textuality of the fabric becomes a matrix of code - translations, networks and hybridities continue, as they always have, to be rapidly multiplied. The trans- sorts, redistributes and expands. As we have seen, on the one hand the trans- serves as a differentiator, for the ancestors are clearly dead. They are no longer present to us as partners in the daily round. Even this deadness of the dead, however, is traversed by the trans-, for our ancestors must, like us, also be living or we would not be making them offerings of burned paper, ghost-money, and all the accoutrements of success to be found in the Mid-Levels or on the Peak. We would not, if they were not living, both fear their presenceand, at the same time, ache for their presence. The ancestors (like us) are the living-dead.

We often wish that the trans- could be singularised into a unity without any of the criss-crossings of ficticity. We wish that all of us could simply be alive together once and for all (though this might create economic quandaries of supply and demand since the desire of both the living and the dead is apparently infinite). If we could just print more cash or multiply digital wealth without limit, however, we would create absolute inflation and everything, consequently, would be without value, whether in this world or the next. There is a clear indication that such inflation has occurred, but there is no Central Bank to curtail its impact (which, in fact, is nothing).

Earlier examples of these notes were issued in denominations of \$5 and \$10 yuan and upwards, with such amounts being considered adequate until inflation took hold within China from 1944. The soaring denominations of authentic currency was soon reflected in that issued for the afterlife, and after 1945 the majority of Hell banknotes were issued in denominations of $\$ 10,000$ or higher. (Wikipedia)

When paper money and what stands behind it in the daylight world reverts to worthless paper alone, the currency of the dead is threatened as well, but it can afford - since it draws on an infinite reserve - to simply add zeroes and print larger bills.

Without limits - say those given by the state around 'legal tender' or of the 'laws' of supply and demand - economic value cannot be set into motion. In the case of ghost-money, then, what are the boundaries, limits and translations at work that create the value of the expenditures by fire? Is there a 'universal equivalent' between the living and the dead or does this equation always already throw things asymmetrically off-balance, thus giving rise to the possibility of meaning, which depends on the disjunctions and imbalances of the relations between (non)sense? 
How do these two currencies float against one another or is there perhaps a 'gold standard' against which each dimension of these currencies are measured? This question of value and measurability emerges as an integral part of the very inauguration of the Greek philosophical tradition in, for instance, Plato's Euthyphro or the Republic. Currencies flow, but they flow only in a deliberative scale of numbers and it is precisely this capacity to flow in measured ways that creates the possibility for value, whether economic or ethical. (What, then, of the immeasurable, and, in particular, of the immeasurability of death?)

There are, in any polity, always social distinctions at work and in the underworld, as in our own, some of the ghosts are privileged and some go begging.

Some died without children; others were unlucky enough to have all their descendants die out; still others have been unable to reach the world of the dead because they had no proper funeral. All these are the underprivileged dead. They get none of the food, paper clothing, and spirit money that are showed upon ancestors, and none of their great respect. And they resent it. That is why they are dangerous. (Scott 2007: 92)

They are dangerous because their spirits are in need of the goods of the living, but they have no one living to care for them, to burn offerings and thereby satiate their hunger.

400 The dead, like the living, have wants and needs in the netherworld, including material goods such as a spirit/soul house (lingwu), which are necessary to keep the ancestors from becoming "hungry ghosts" and to help them live through the required period in the netherworld ...' (Kuah-Pearce 2011: 142). Seeking blood or money, the homeless in the under- and afterworlds are hauntological wanderers who can cross the supposedly firm boundary between the living and the dead. Neither a proper funeral nor ongoing ritual offerings have been made, so these unpropitiated spirits cannot be contained, kept fixed into the proper place of the dead. They linger inside the banks or they linger on the late night streets, all the while waiting for the gullible or the careless to wander by.

The dead must be paid off with protection money by the living, but there are neither monthly payment plans that can erase an interest rate nor an end to the debt, at least not until the living pays her debt for the gift of existence with her life and becomes a ghost herself. The living and the dead are conjoined in a state of need, but no form of payment - however exorbitant, as with the recently minted trillion dollar notes of ghost-money - can ever put a final stop to the circulation of money, paper goods, longing, fire and smoke that mingle in the act of a communicative transfiguration accomplished by the burning of paper into the more subtle forms of ash. Need circulates.

In numerous instances, quantification and money, together, resacrali[s]e exchanges and conversions ... with the dead, for example in the burning of ghost moneys (which have taken on special significance in the wake of economic transition in China and Vietnam) ... 
One suspects that moral assessments of certain adjectivally marked moneys - dirty money, hot money, bitter money, money that burns like oil, 'liquid' money . . . derive from those moneys' positions as hinges between short-term and long-term transactional orders . . . (Mauer 2006: 35, italics mine)

The hinge is the sign of the trans- of hybridity. Money provides an abode for wishes, blood and histories. There are, to be sure, moments of satiation, but the rule is not 'your money or your life', but 'your money and your life'. What is the price of a life? Society constantly makes this judgment and time puts a price on all of our heads in a bounty that will be paid, but at least until the death of the dead, can never be paid off.

We must all keep making money in the daylight world of work so we can pay off our unpayable debts in the world of the shadows. This is the infinite desire of the dead, which mirrors in a refracted form the infinite desire of the living. Both want to keep living well, to have a roll of bills stuck in the back pocket or a large number on the ATM printout. Who doesn't want to be rich? On arriving in the next world, the soul of the dead needs money to pay the heavy ransom demanded by Yu Huan for its release from bondage or to satisfy other creditors waiting there who need funds for their release.

All of the burned paper goods must travel to the dead as the image of the memory of the form of the objects, since the paper object is now ash in the embers of a temple, a home, or in one of the small street-side altars found all over Hong Kong. The goods and the money all travel via fire, accompanied by the wind and by words whispered to the fire, to the wind. These offerings through the act of burning imply that incineration is an act whose effects are contradictory: in this world, the object is destroyed, while in the invisible one this act has a positive result' (Hou 1975: 92, my translation). The object, displaced, is teleported from one world to the other; it vanishes only to reappear once again, scarred and reconstituted by flame.

Large quantities of money are required in order for those who precede us to become happily dead, especially since the dead, like the living, want to live the good life of high-end cars, high-rise apartments, and high-tech gadgets. As early as the twelfth century in China, according to Scott, paper money had already become a standard item in funeral rituals to meet this demand for release.

Each person was born into this world by borrowing money from the bank of the underworld. Each person stayed alive only so long as the term for payment had not ended. At death each person was required to pay in full the loan contracted at birth. (Scott 2007: 26, citing Teiser)

Forgive us our debts as we forgive each other. We live on borrowed time until one fine and unexpected day the note comes due and we vanish like smoke. ${ }^{5}$

${ }^{5}$ In 'Anaximander's Saying', Heidegger develops a meticulously dense translation of the passage that comes to us as the oldest extant Greek philosophical fragment. Generally, it has been translated as, '[b]ut that from which things have their 
Discussing the 'voodoo' and 'mirror' economics of the Reagan-Thatcher years - and very much continuing into the present - David Harvey notes that

the emergence of the casino economy, with all of its financial speculation and fictitious capital production (much of it unbacked by any growth in real production) provided abundant opportunity for personal aggrandizement ... [T]he obverse side of the affluence was the plague of homelessness, disempowerment, and impoverishment that engulfed many of the central cities. (Harvey 1990: 356)

This speculative mode of capitalism led to the crash of Black Monday on 19 October 1987, when more than a third of the world's paper assets were wiped out, as if by fire or magic, and to the global debacle of the 2008 subprime disaster 'triggered' by the fall of Lehmann Brothers, which of course was only a symptom of the economic greed of an unregulated casino capitalism.

Money, of whatever sort, depends on more encompassing symbolic networks of exchange, but money as depositable and transactionable for goods and services in the present - Anwesenheit, Heidegger's preferred term for 'presence' in his later work, is connected to the naming of Being as ousia or parousia 'in a sense which basically means the "estate," the immediate and always present possession, the "property"' (Heidegger 1997: 168) ${ }^{6}$ - would be linked with, but distinguishable from, the money for the ghosts, the gods and the ancestors. As an intermediate form of this continuum of exchanges, all of which are operated on by different series of translations, we could examine instances when worthless money, say from a fallen regime, becomes a collector's item to be purchased or when 'money' becomes 'art', as in the case of J.S.G. Boggs, whose art acts like money by generating goods and services on the spot, in the present.

arising also gives rise to their passing away according to necessity; they give justice and pay penalty to each other for the injustice according to the ordinance of time'. Heidegger notes that the 'usual view' of the passage is that it simply observes that '[T]hings develop and then they decay, exhibiting thereby a kind of barter system of nature's unchanging economy' (Heidegger 2002: 248). After developing his own reading, Heidegger translates the passage as 'alongside the line of usage; for they let order and reck belong to one another (in the surmounting) of dis-order', admitting that we can 'only reflect on the translation by thinking through the saying. Thinking, however, is the poeticizing of the truth of being in the historical dialogue between

510 those who think' (Heidegger 2002: 280). This is not the time to follow the translation in detail, but suffice it to say that analytic links between nature's 'barter system', the 'dis-jointure' of the between, and the presencing of being, especially by the seer who 'sees the future tense out of the perfect' (260) - could help illuminate the 'debts' to be paid by the living and the dead.

${ }^{6}$ See also The Essence of Human Freedom (1997: 36-37). Kant and the Problem of Metaphysics was first published in 1929, The Essence of Human Freedom in 1930.

${ }^{7}$ See Lawrence Weschler, Boggs: A Comedy of Values for delightful discussion of the many-faceted relationship between art, money, the 'original' and value. 
Marx, Simmel and Weber understood money under capitalism, Mauer argues, to be a kind of

[u]niscalar valuation and universal commodification were seen as the hallmarks of modern, capitalist money, and as eroding other societies' systems of value, flattening the dense and complex networks of value formation that had previously been built on distinctions of gender, rank, age, and status. Money makes inanimate things reproduce and confounds categories among human, spirit, and natural worlds ... (Mauer 2006: 21)

This 'confounding of categories' is perfectly expressed by the performative action of ghost-money. We pay with 'real' money for 'fake' money in a paper-goods shop; but this 'fake' money then buys 'real' value in the spiritworld, which we have access to only by sending the 'fake' money ahead via the consumption by heat and flame into a transfigured and smoky body of value and respect.

The concept and function of rationality depends precisely on the fantasy that categories - a term that follows philosophy from close to its inception can be separated one from the other ('purified' in Latour's sense) and kept bounded by impermeable membranes. In fact, to accomplish the work of the rational - whether in language or in number - one must depend upon the order of a pre-established logic. But membranes are all finally permeable and the pre-rational acts that excise the others of rationality for the putative sake of rationality cannot be kept at a requisite distance. Like smoke, like ash, like ghosts: they float, hover, return, forming reflective mirages in our systems of accountabilities.

This is not, of course, to deny the extreme value and usefulness of the rational as a domain of action, but it is to recognise its essential limits and to refuse to valorise it as the highest good that obscures ficticity, the wondrous, the moods, the contingent and the absolute proximity of death. This finitude opens toward all the multiple others of the rational as the formality of logic. The fact that there is something like the rational is itself wondrous, but if the rational usurps all the other categories of experience it becomes, like all idolatries, destructive. 'Between the electrum of ancient Lydian coins to the electronic currencies of the present day', Mauer reminds us, 'money has been a metaphor for and exemplar of the problem of the relationship between sign and substance, thought and matter, abstract value and its instantiation in physical and mental labors and products' (Mauer 2006: 27). Ghostmoney, confounding categories, operates as a trans- across all of these distinctions: transfer, translation, transaction, transubstantiation.

Ghost-money occurs as one of the nodes of a nonmodern network that criss-crosses Hong Kong's hypermodernity that swarms along the streets, digitises the stock exchange as it connects to Shanghai for its throughtrades, zips signals through the fibre optic cables and into near-earth orbit, creates feng shui in the architecture of the global banks and burns patiently, with an immemorial memory, in the temples, redolent with the fragrance of incense, throughout the city. Ghost-money both extends current forms of capitalist consumption to which Hong Kong is habituated, and, with the dead 
waiting expectantly just around the corner of experience, simultaneously critiques this consumption that will not, whatever type of car we drive here or there, protect us from exposure to the debt of finitude. Still commenting on Cassirer's presentation of mythic symbolic consciousness, Heidegger notes that:

A basic feature of mythical consciousness of objects is the fact that a demarcated boundary is lacking between what is dreamt of and what is experienced while awake, between what is merely imagined and what is perceived, between image and the object that is formed in the image, between word (meaning) and thing, between what is merely wished for and what is actually possessed, and between what is living and what is dead. Everything remains in one uniform level of Being that is immediately present, by which mythical Dasein is dazed. (Heidegger 1997: 181)

We are all, then, still dazed, but not quite, perhaps, in the same way. Although it is the case that we have never, as Latour reminds us, been modern, it is also true that we have lived within, though not yet by any means to the other side of, the multidimensional matrices of the Constitution of Modernity with its relationships to nature, society, the divine and subjectivity.

This marks an important difference of inflection and enables us to understand ghost-money through a score of the critical grids of modernity including anthropology, sociology, political economy, semiotics, the history of money, art, philosophy and psychoanalysis. But this understanding does not erase the physical and symbolic movement of ghost-money. Critique does not ultimately dissolve the object of critique - whether of ideology, false consciousness, the nonsense of metaphysics or suppressed memories - but it does reposition the object away from the literalisms of ideology and more toward the function of symbolic play (which, of course, continues to be illuminating). As Blake obseryes, the ghost bills

entail a paradigm shift in the paper money tradition that more or less coincides with the shift in China's historical formation, from developed feudal to hypermodern in the space of a century or, with ever greater intensity and completeness, in the space of the last three decades ... With the mutation of state-based capitalisms into international corporate-based global capital, reification is simulated through semiosis. To the extent we want to view this in the totality of historical dialectics, we would have to say that thus far capitalist civili[s]ation has moved the human spirit toward an alienation of historic profundity. (Blake 2011: 169, 214)

The global financialisation of capitalist practice and the critical analysis of the neoliberal paradigm are both continuing endeavours, but neither 'explains away' the ritual practice of burning money and sending it toward the other side. Money of any sort is an assemblage that conjoins the rational and its others, a trans-rational wildcard that brings calculation, story, history, desire and image along with its every transaction. 
We burn through money as if there will be no tomorrow, but just as we burn money, money also burns through us, coursing like a fiery currency through our fingers, our veins and out on to the streets. It is killing us as we spend down our time and prepare for that which cannot be prepared for: our own becoming-ghosts, spirits in need of cash and other paper goods forwarded to us posthumously from those we have left behind. We, too, will be hungry ghosts looking to live as well as we can while we spend our money dying the next death so that we can dissolve the last curled ash of that life-indeath and that death-in-life. As if, having finally paid all of our debts, we will at last be able to separate the one from the other and then vanish for good: smoke in the wind.

\section{Acknowledgments}

I would like to thank the anonymous reviewers of the essay as well as Colin Danby, Seth Henderson, Khun Eng Kuah-Pearce, Selina Lai-Henderson, David Palmer and Scarlet Poon for their generous support and expertise.

\section{Disclosure statement}

No potential conflict of interest was reported by the author.

\section{ORCID}

Gray Kochhar-Lindgren id http:/ orcid.org/0000-0002-5593-0753

\section{References}

Berger, J. 2013. Understanding a Photograph. Geoff Dyer (ed). London: Penguin.

Blake, C. F. 2011. Burning Money: The Material Spirit of the Chinese Lifeworld. Honolulu: University of Hawaii Press.

Derrida, J. 1997. 'Point de Folie - maintenant l'architecture'. In Neil Leach (ed), Rethinking Architecture: A Reader in Cultural Theory. London: Routledge, 324-336.

Gates, H. 1987. 'Money for the Gods'. Modern China 13:3, 259-277.

Guyer, J. 2004. Monetary Gains: Monetary Transactions in Atlantic Africa. Chicago: University of Chicago Press.

Harvey, D. 1990. The Condition of Postmodernity: An Enquiry into the Origin of Cultural Change. Cambridge, MA: Blackwell Publishing.

Heidegger, M. 1997. Kant and the Problem of Metaphysics. translated by Richard Taft. Bloomington: Indiana University Press.

Heidegger, M. 2002. 'Anaximander's Saying'. In Julian Young and Kenneth Haynes (eds), Off the Beaten Track. Cambridge: Cambridge University Press.

Heidegger, M. 2012. The Essence of Human Freedom: An Introduction to Philosophy. translated by Ted Sadler. London: Continuum.

Hou, C.-L. 1975. Monnaies d'offrande et la notion de tresorerie dans la religion chinoise. Paris: College de France, Institut des Hautes Etudes Chinoises.

Kuah-Pearce, K. E. 1989. 'Gods, Spirits and Humans in Chinese Cosmology'. Criticism, Heresy and Interpretation 3, 91-96.

Kuah-Pearce, K. E. 2011. Rebuilding the Ancestral Village: Singaporeans in China. Hong Kong: Hong Kong University Press. 
Latour, B. 1993. We Have Never Been Modern. translated by Catherine Porter. Cambridge, MA: Harvard University Press.

Marx, K. 1841. The Difference Between the Democritean and Epicurean Philosophy of Nature. Available online at https://marxists.anu.edu.au/archive/marx/works/1841/drtheses/foreword.htm (accessed 12 February 2015).

Mauer, B. 2006. 'The Anthropology of Money'. Annual Review of Anthropology 35, $15-36$.

Scott, J. L. 2007. For Gods, Ghosts and Ancestors: The Chinese Tradition of Paper Offerings. Hong Kong: Hong Kong University Press.

Weschler, L. 1999. Boggs: A Comedy of Values. Chicago: University of Chicago Press.

Wikipedia. 'Hell-Money'. Available online at http://en.wikipedia.org/wiki/Hell_ money (accessed 22 November 2014).

Gray Kochhar-Lindgren is Professor and Director of the University of Hong Kong's Common Core, working with multiple partners to deepen the interdisciplinary general education experience of the university's students. With a $\mathrm{PhD}$ in Interdisciplinary Studies from Emory University, he has taught in the United States, Switzerland and Germany, and, in 2009-2010, served as a Fulbright Scholar at the Hong Kong American Center and the University of Hong Kong. The author of Narcissus Transformed; Starting Time; TechnoLogics; Night Cafe; Philosophy, Art, and the Specters of Jacques Derrida; and Kant in Hong Kong: Walking, Thinking, and the City, Dr Kochhar-Lindgren is currently working on philosophy in the streets, abiding with the impossible and the global transdisciplinary university.

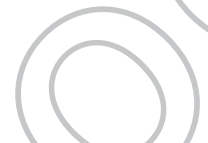

